\title{
In silico study the interaction of heterocyclic bases with peptide moieties of proteins in "fragment-to-fragment" approach
}

\author{
Yevheniia S. Velihina $^{1}$, Nataliya V. Obernikhina ${ }^{2 *}$, Stepan G. Pilyo ${ }^{1}$, Maryna V. Kachaeva ${ }^{1}$, \\ Oleksiy D. Kachkovsky ${ }^{1}$ \\ ${ }^{1}$ V. P. Kukhar Institute of Bioorganic Chemistry and Petrochemistry of the NAS of Ukraine, 1 Murmanska St., Kyiv, 02094, Ukraine \\ ${ }^{2}$ O. O. Bogomolets National Medical University, 13 Shevchenko Blvd., Kyiv, 01601, Ukraine
}

\begin{abstract}
The binding affinity of model peptide moieties (Pept) and heterocyclic bases involving 1,3-oxazoles that are condensed with pyridine and pyrimidine as pharmacophores (Pharm) was investigated in silico and analyzed within the "fragment-to-fragment" approach. The anellation of the heterocyclic rings increasing their acceptor properties is accompanied by gaining stability of the [Pharm-Pept] complexes formed by the $\pi, \pi$-stacking interaction. It was found that elongation of the polypeptide chain led to a twofold increase of the stabilization energy of the [Pharm-Pept] complexes. The stability of the hydrogen bonding ([HB]) [Pharm-BioM] complexes formed by means of the interaction between the dicoordinated nitrogen atom of the heterocycle and the functional groups of peptide amino acids $\left(-\mathrm{OH},-\mathrm{NH}_{2},-\mathrm{SH}\right)$ was evaluated. It was demonstrated that $[\mathrm{HB}]$-complexes that were formed by hydrogen bonds formation with amino acid that contained $\mathrm{OH}$ groups had the largest stabilization effect. The anellation with pyridine and pyrimidine rings led to stability increase of the complexes formed by the hydrogen bonding mechanism. The binding energy of [HB]-complexes for compounds $\mathbf{2} \mathbf{b}$ and $\mathbf{3}$ with a "free" peptide bond of the extended part of the protein is lower compared to amino acids with OH-functional groups. On the contrary, the binding energy of compound $\mathbf{4}$ with peptides was $2 \mathrm{kcal} / \mathrm{mol}$ higher. Compound $\mathbf{4}$ demonstrated the most pronounced biological activity in vitro studies.
\end{abstract}

Keywords: fragment-to-fragment approach; peptide bond; biological affinity; [Pharm-BioM] complex; $\pi$, $\pi$-stacking interaction; hydrogen bonding.

\section{Introduction}

The heterocyclic ring systems containing both nitrogen and oxygen, such as substituted 1,3-oxazoles, are very suitable for use in drug design and library design, which has allowed the introduction of a number of novel pharmacological agents in medical practice (see for example reviews [1-2]). The 1,3-oxazoles with branched conjugated systems have revealed higher biological activity including antibacterial and antiviral activities [3-4], and multiple drug resistance pump inhibition [5-6].

\begin{tabular}{ll} 
Received: & 27.04 .2021 \\
Revised: & 06.05 .2021 \\
Accepted: & 08.05 .2021 \\
Published online: & 30.06 .2021 \\
\hline
\end{tabular}

* Corresponding author. Tel.: +380-96-225-7764; e-mail: nataliya.obernikhina@gmail.com (N. V. Obernikhina) ORCID: 0000-0003-1143-8924
It was found that these compounds can be considered as a promising component in the development of new biologically active substances that exhibit antitumor activity in a strong dependence on the nature of the substituents in the heterocycle [7-10]. This has enabled the wide introduction of novel pharmacological remedies in clinical practice [11-12]. The QSAR models have been developed for a large series of 1,3-oxazole derivatives showing inhibitory effect on some cancer cell lines and demonstrating a good correlation between many descriptors and biological activity [14].

Determination of a mechanism of multiple ligand binding affinity for amino acids in binding and regulatory proteins is currently an actual task for researches. Binding cavities on protein surfaces are important for protein function because they are usually the sites at which a protein binds to other biological macromolecules such as other proteins and nucleic acids, or small molecules such as metabolites and pharmacophores [15]. 
Table 1. Chemical structures of the compounds 1-2(a-c) and 3-6.

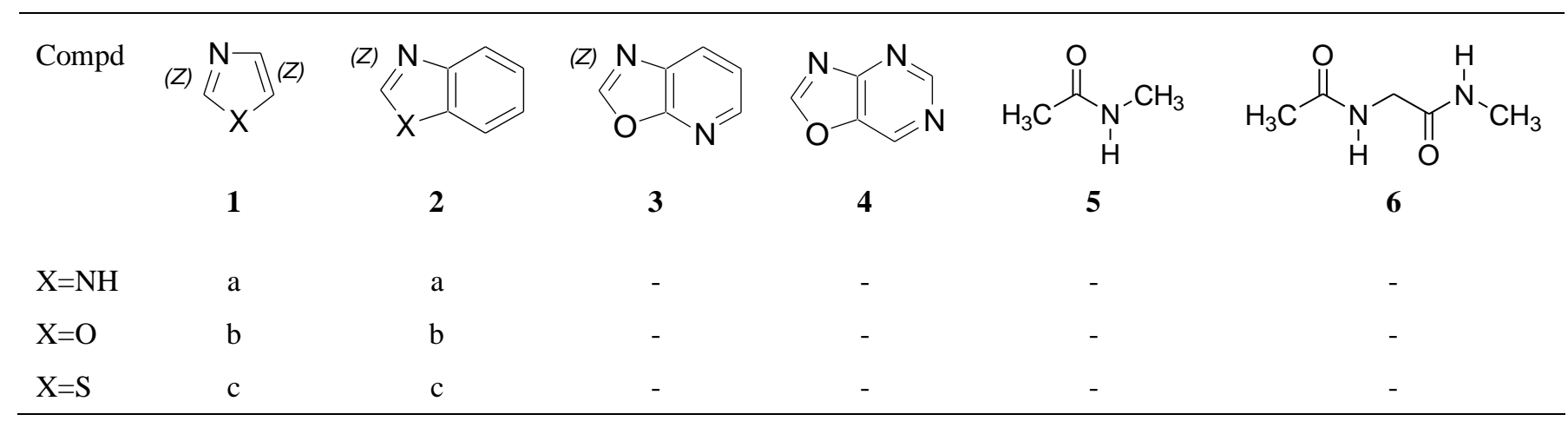

Therefore, in order to minimize energy of formation of the Pharmophore Biomolecule ([Pharm-BioM]) complex, structure and electronic properties of the pharmacophore should be as close as possible to the corresponding real protein cavities [16]. The interaction between ligands and proteins usually induces changes in structure and conformational flexibility of the protein. These modifications are due to the coupling of unfolding with binding equilibrium [17-18]. In this regard, it could be expected that modifications in protein stability correlate with changes in the protein packaging caused by ligandpharmacophore binding due to various types of bond formation, including the formation of a pharmacophoreligand bond with a "free" peptide bond, not untwisted part of the protein.

Over the past two decades, the Fragment-Based Drug Discovery (FBDD) strategy has been considered in the pharmaceutical industry as a successful key technology for early-stage drug discovery and development [19-20]. This strategy consists of screening low molecular weight compounds (pharmacophores) against macromolecular targets (usually proteins) of clinical relevance. Previously, the "fragment-to-fragment" approach has been used for studying interactions between oxazole and its derivatives with aromatic acid residues in the protein molecule in [Pharm-BioM] complexes formed on the basis of the $\pi, \pi$-stacking interactions [21-23]. The oxazole cycle contains two-coordinated nitrogen atom with a lone electron pair (LEP); therefore, it can be considered as a donor center for the formation of [Pharm-BioM] complex with amino acid residues of proteins such as lysine, arginine and histidine by the mechanism of hydrogen bonds interaction.

This paper presents the results of in-silico studies of the stability of the [Pharmophore-Peptide] complex formed between peptide moieties in a model protein and heterocycles as pharmacophores using the "fragment-to fragment" approach.

\section{Materials and calculation method}

It was found that oxazole derivatives demonstrated their biological activity [24-26] associated with their ability to form a stable [Pharm-BioM] complex. The oxazole mole- cule has two distinctive features: 1) it contains a branched $\pi$-system, therefore, it can form a complex due to the $\pi$, $\pi$-stacking interactions with suitable conjugated fragments of biomolecules; 2) it contains the dicoordinated nitrogen atom with the LEP and, therefore, can form the complex due to a hydrogen bond when this atom is a proton acceptor. Then, in this paper, the possible expansion of the conjugate system and the increase the number of the LEPs in the anellated compounds $\mathbf{1 - 4}$ were investigated. Of course, the real pharmacophore molecules contain both the conjugated and non-conjugated substituents. However, in this study, only the heterocyclic moieties will be considered.

Regarding the polypeptide chain, only the model molecules containing one and two peptide bonds are studied (Table 1, structures $\mathbf{5}$ and $\mathbf{6}$ ).

The double bond of the $>\mathrm{C}=\mathrm{O}$ group and the LEP of the nitrogen atom form a short conjugated system, while the LEPs of the oxygen atom could take part in the formation of hydrogen bonds with hydrogen atoms. So, here we will consider only the complex of molecules 1-4 with model molecules $\mathbf{5 ,} \mathbf{6}$ formed by the $\pi$, -stacking interactions and hydrogen bonds.

The main characteristics of the electron structure (optimized molecular geometry, charge distribution, energies and shapes of molecular orbitals) were calculated by DFT [wB97XD/6-31G(d.p.)] method (package GAUSSIAN 03 [27]).

\section{Results and Discussion}

\section{Possible interaction compounds 1-4 and its derivatives with the peptide bonds}

According to theoretical conception, the capacity of the organic molecules to form stable complex with biomolecules is essential condition of the biological activity; it is designated as its affinity or biological affinity [28-29]. Then, pharmacophore [Pharm] and biological molecule Peptide [Pept] form the stable complex [Pharm-Pept]:

$$
[\text { Pharm }]+[\text { Pept }] \rightleftharpoons \text { Pharm-Pept }]
$$


The complex stability depends on the electronic environment of both components. We supposed that the complex and its component are neutral and hence no electron redistribution between the components upon complexation occurs [30]. Stabilization energy of the complex (or binding energy $\mathrm{E}_{\text {bind }}$ ) was estimated as the difference of the total energies of the complex its components:

$\mathrm{E}_{\text {bind }}=\mathrm{E}[$ Complex $]-\mathrm{E}_{[\text {Comp 1] }}-\mathrm{E}_{[\text {Comp 2] }}$

where $\mathrm{E}_{\text {[Complex] }}$ is energy of the optimized complex, while $E_{\text {[Comp 1] }}$ and $E_{[\text {Comp 2] }}$ are energies of both optimized components.

Recently, the "fragment-to-fragment" approach was proposed [22-23], which could be considered as the next step in silico modeling. It divides the total interaction into the particular components and hence enables estimating the interaction energies between fragments by the more correct non-empirical quantum-chemical methods, i.e. it taken into consideration the chemical and electronic structures of the complex and those of the both components.

In this paper, the so-called hydrophobic interaction is not considered. It should also be noted that the formation of conformational formations of the polypeptide chain is accompanied by the stabilization of protein structures through the formation of hydrogen bonds between $-\mathrm{NH} \bullet \cdot \mathrm{O}=\mathrm{C}$ peptide fragments. In the helix, then, the peptide bonds that form the protein conformation do not interact effectively with the pharmacophore molecules. Pharmacophores can form complexes only with "free" peptide bonds of the untwisted part of the protein.

Generally, the stack interaction between two $\pi$-electron systems A (Pharmacophore) and B (Biomolecule) is determined by the relative positions of the molecular levels of both molecules, can be estimated by perturbation theory [31], using the following equation (2):

$$
\Delta \mathrm{E} \approx \sum_{\mu}^{A} \sum_{i}^{A} \sum_{v}^{B} \sum_{j}^{B}\left[\frac{C_{i \mu} C_{j v}}{\varepsilon_{i}-\varepsilon_{j}}\right]
$$

where $\varepsilon_{\mathrm{i}}$ and $\varepsilon_{\mathrm{j}}$ are $\mathrm{MO}$ energies; $\mathrm{C}_{\mathrm{i} \mu}$ and $\mathrm{C}_{\mathrm{j} v}$ are $\mathrm{MO}$ coefficients; nieces $\mathrm{i}, \mu \in$ system $\mathrm{A}$, while indices $\mathrm{j}, \nu \in$ system B; the first two sums run over all levels, whereas second two sums run over all atoms ( $\pi$-centers).

Equation (2) implies that interactions between the occupied levels of one component (Pharmacophore) with the vacant levels of another component (Peptide) should be effective, while interactions between the occupied levels or vacant levels of both components should not be effective. Of course, the interaction amplitude depends on the overlap of the orbitals (or more exactly, on the coefficients $\mathrm{C}_{\mathrm{i} \mu}$ ). The molecular levels of the components will be discussed later.

\section{Molecular characteristics of complex components} studied

Planarity and geometrical dimensions of molecules

Optimized structures of molecules 1-6 and corresponding complexes are planar, what is typical for the conjugated systems; this planarity is not disturbed upon complexation. Molecular dimension of the complex components are in the same order; they are presented in Figure 1.
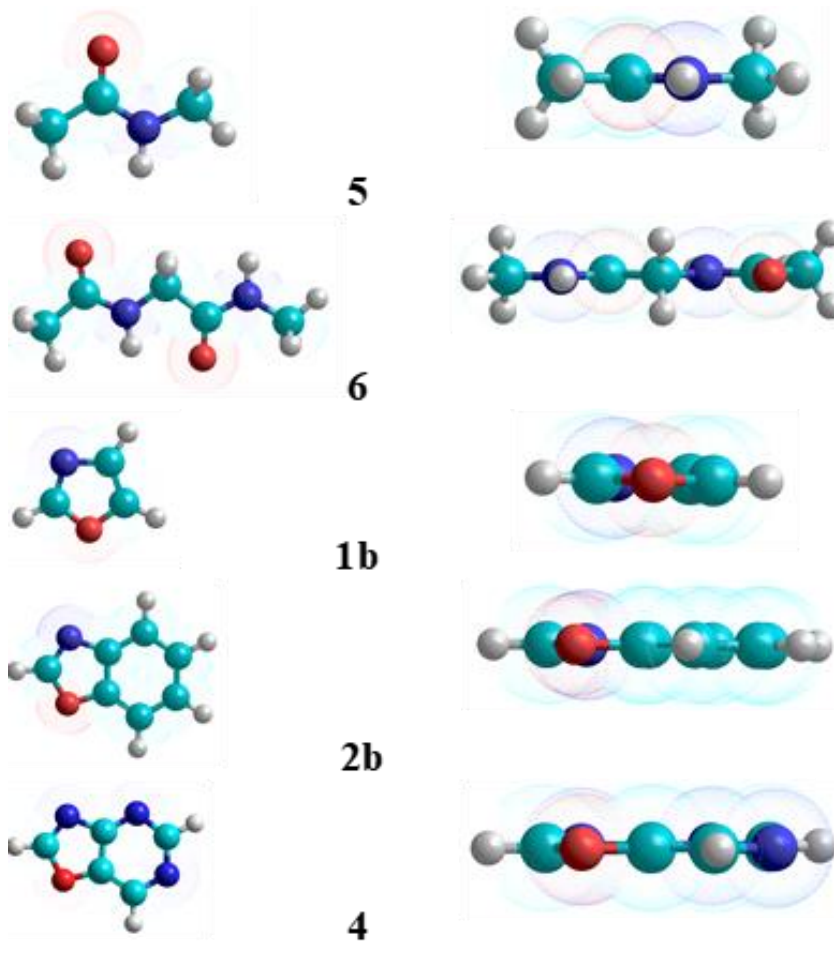

5

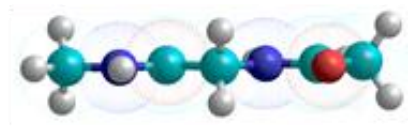

6

$1 \mathbf{b}$

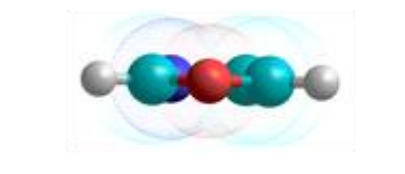

2b

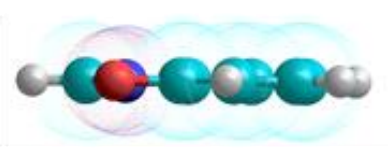

4

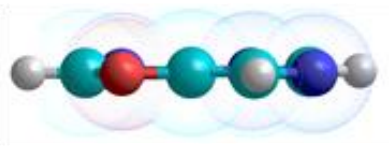

Figure 1. Optimized geometry of the compounds $\mathbf{1 b}, \mathbf{2 b}, \mathbf{4 - 6}$ (modeled using the HyperChem package).

Azoles 1 and their derivatives 2-4 take the molecular volume: the thickness of $\pi$-electron shell is $\approx 3.4 \AA$; then the estimated values for the oxazole cycle is $\approx[6 \times 6 \times 3,4] \AA^{3}$; for the anellated derivatives it is $\approx[7 \times 8,5 \times 3,4] \AA^{3}$; for the model peptide 5 it is $\approx[7 \times 5 \times 3,4] \AA^{3}$; for the model dipeptide 6 it is $\approx[11 \times 7 \times 3,4] \AA^{3}$. The hetero-substitution $\mathrm{O} \rightarrow \mathrm{S} \rightarrow \mathrm{NH}_{2}$ somewhat increases the molecular volume.

As it follows from Figure 1, molecules 1-4 can form the binary [Pharm-Pept] complex by $\pi, \pi$-stacking interactions with only one $\pi$-system of the peptide; the bicyclic molecules 2-4 could form the complex with two $\pi$-moieties in dipeptide $\mathbf{6}$.

The Lone electron pair (LEP) and n-molecular orbitals $(M O)$ dicoordinated nitrogen atoms.

As the molecules 1-4 contain dicoordinated nitrogen atoms, then $n$-MOs occurs in the electron shell beside $\pi$ levels. The corresponding LEPs can participate in hydrogen bonds; the corresponding interaction energy depends on the dispositions of the $n$-levels. For sake of illustration, the 

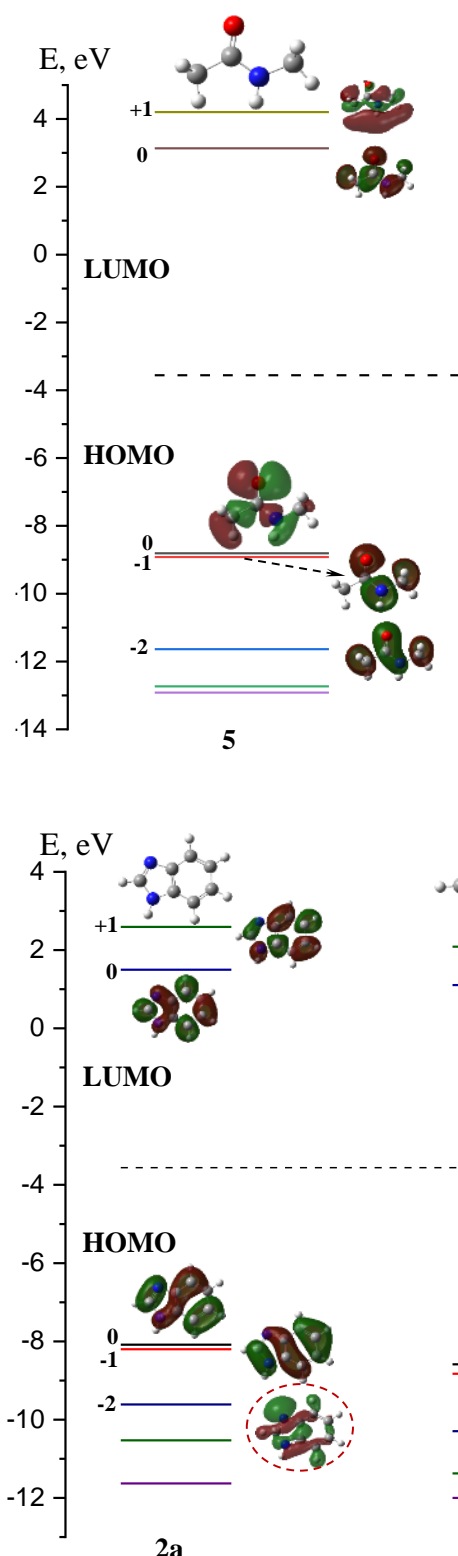

2a

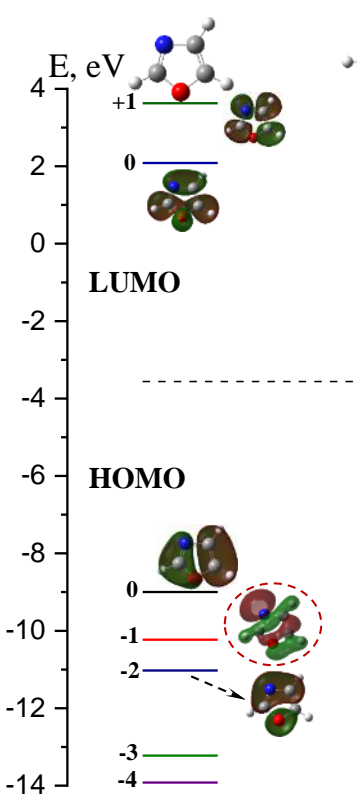

$1 \mathbf{b}$

$\mathbf{2 b}$
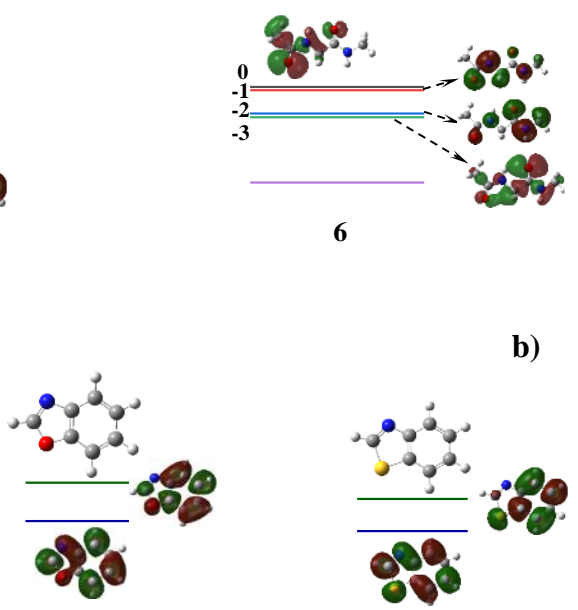

b)

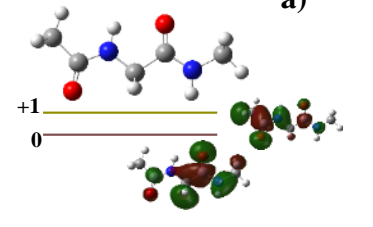

Fermi level

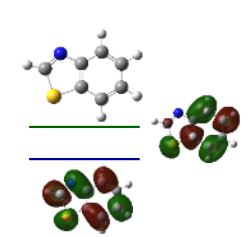

Fermi level

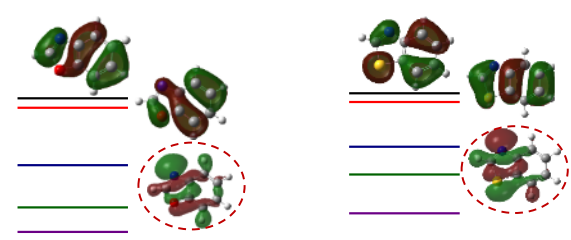

$2 \mathbf{b}$

$2 \mathrm{c}$

c)

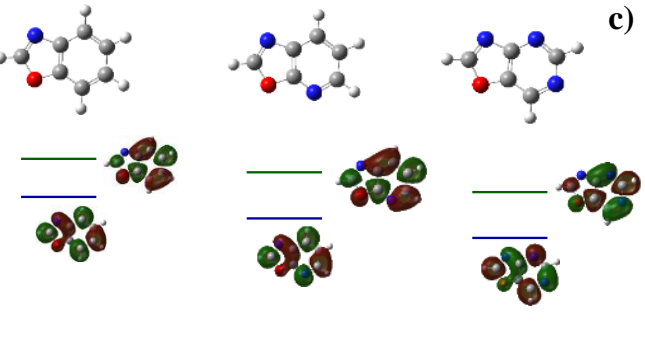

Fermi level

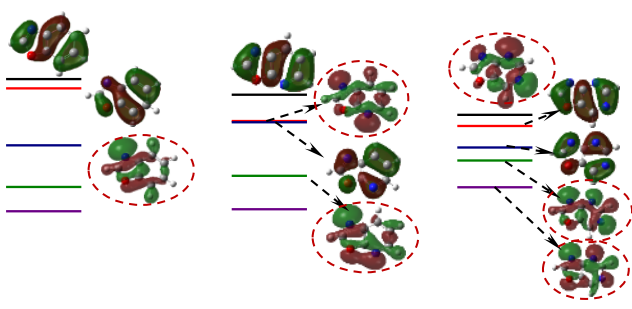

3

4

Figure 2. Shape of frontier MO and $n$-MO in the peptides 5-6 (a), compounds $\mathbf{2 a - 2 c}$ (b) and $\mathbf{1 b}, \mathbf{2 b}, \mathbf{3}, \mathbf{4}$ (c) 
energies and shapes of the frontier and nearest MOs in the oxazole $\mathbf{1}$ and its anellated derivatives $\mathbf{2 - 4}$ as well as the model peptide $\mathbf{5}$ and dipeptide $\mathbf{6}$ are pictured in Figure 2.

Elongation of the polypeptide chain (introduction of the second peptide unit), as shown in Figure 2a, leads to an asymmetric distribution of electron density in the dipeptide. This distribution must be taken into account when interacting with the pharmacophore by the $\pi$-stack mechanism. The $n$-molecular orbital (n-MO), which is "responsible" for the formation of a hydrogen bond in complex formation, as shown in Figure $2 b$, is not sensitive to the replacement of the heteroatom $X$ in compounds 2 : it remains HOMO-2, although it has slightly different energy value, which was also shown earlier on monocyclic 5-membered heterocycles [23].

Expansion of the conjugation system of the studied compounds 1a-1c due to anellation $(\mathbf{1} \rightarrow \mathbf{2})$ leads to the appearance of a new highly positioned $\pi$-MO; therefore $n$-MO is now HOMO-2. At the same time, the addition of the pyridine acceptor cycle leads to the appearance of an additional (pyridine) $n$-MO, which is much higher in energy (HOMO-1), and the $n$-MO of the heterocycle shifts downward (HOMO-3) (Figure 2c). Annelation by a more pyrimidine acceptor cycle causes the appearance of another additional $n$-MO, which occupies the HOMO position, and a subsequent shift in energy of $n$-MO of the heterocycle makes it HOMO-4 (Figure 2c). It should be noted that the interaction of the additional $n$-MOs with each other is accompanied by their splitting, which causes a greater shift of the $n$-level to higher orbital energy. Besides, such a change in the mutual position of the $\pi$-levels and $n$-levels should affect the stability of the [Pharm-Pept] complex stabilized by hydrogen bonds.

Index $\varphi_{0}$ as a quantitative characteristic of donoracceptor properties

It was proposed earlier [32] to estimate quantitatively the donor-acceptor properties of the conjugated molecules analyzing positions of the frontier MOs relatively to the non-bonding $\pi$-level (so-called Fermi level of $\pi$-electrons) $\varphi_{0}$; this parameter is calculated by equation (3):

$\varphi_{0}=\left(\varepsilon_{\text {LUMO }}-\alpha\right) / \Delta$

where $\Delta=\varepsilon_{\text {LUMO }}-\varepsilon_{\text {HOMO }}, \varepsilon_{\text {LUMO }}$ is the energy of the LUMO; $\varepsilon_{\text {Hомо }}$ is the energy of the HOMO; $\alpha=-3.56 \mathrm{eV}$ is the energy of Fermi level (the middle of the HOMO-LUMO gap for the polyene with 15 double bonds) [33].

If the energy gap $\Delta$ is symmetrical relative to the virtual level $\alpha$, then $\varphi_{0}=0.5$ and hence the donor and acceptor properties are mutually balanced; the shift of the energy gap up (and hence increase of the parameter $\varphi_{0}>0.5$ ) indicates a mainly donor nature of the conjugated molecule; on the contrary, if $\varphi_{0}<0.5$, then the frontier levels are shifted down, evidencing a predominately acceptor nature [32]. The calculated MO energies and parameter $\varphi_{0}$ of molecules studied 1-6 are collected in Table 2.
Table 2. MO energies and parameter $\varphi_{0}$ of the compounds 1-2(a-c) and 5, 6.

\begin{tabular}{cccccc}
\hline \multirow{2}{*}{ Compd } & $\mathrm{X}$ & \multicolumn{2}{c}{$\varepsilon^{\mathrm{a}}, \mathrm{eV}$} & \multirow{2}{*}{$\Delta^{\mathrm{b}}{ }^{\mathrm{c}}$} \\
\cline { 3 - 4 } & & HOMO & LUMO & & \\
\hline $\mathbf{5}$ & & -8.57 & 3.34 & 11.91 & 0.579 \\
$\mathbf{5}$ (cis) & & -8.72 & 2.97 & 11.69 & 0.558 \\
$\mathbf{6}$ & & -8.60 & 2.11 & 10.71 & 0.530 \\
$\mathbf{6}$ (cis) & & -8.60 & 2.12 & 10.72 & 0.530 \\
$\mathbf{1 a}$ & $\mathrm{NH}$ & -8.12 & 2.59 & 10.71 & 0.574 \\
$\mathbf{1 b}$ & $\mathrm{O}$ & -8.86 & 1.67 & 10.53 & 0.497 \\
$\mathbf{1 c}$ & $\mathrm{S}$ & -8.27 & 0.64 & 8.91 & 0.471 \\
$\mathbf{2 a}$ & $\mathrm{NH}$ & -8.05 & 1.34 & 9.39 & 0.522 \\
$\mathbf{2 b}$ & $\mathrm{O}$ & -8.54 & 0.88 & 9.42 & 0.471 \\
$\mathbf{2 c}$ & $\mathrm{S}$ & -8.42 & 0.79 & 9.21 & 0.472 \\
& Polyene-15 & -6.21 & -0.91 & 5.30 & 0.500 \\
\hline
\end{tabular}

${ }^{\mathrm{a}} \varepsilon$ is energy of orbital;

${ }^{\mathrm{b}} \Delta=\varepsilon($ LUMO $)-\varepsilon($ HOMO $)$;

${ }^{\mathrm{c}} \varphi_{0}=[\varepsilon(\mathrm{LUMO})-\alpha] / \Delta[33] ; \alpha=-3.56137 \mathrm{eV}[33] ;$

${ }^{\mathrm{d}}$ see [32].

Table 2 demonstrated that the model peptides 5 and $\mathbf{6}$ (as electron-excessive $\pi$-systems) are donor molecules, whereas compound $\mathbf{1}$ and anellated derivatives 2-4 are acceptors. Also, one can see that expansion of the $\pi$-conjugated system by anellation decreases firstly the LUMO energy, then parameter $\varphi_{0}$ decreases also regularly in the series of the compounds 1-2-3-4. It can be assumed that the interaction of peptides as donors should be more efficient with heterocycles $\mathbf{2 - 4}$ as stronger acceptors.

\section{[Pharm:Pept] Complex stabilized by stacking $\pi$-inte- raction}

Going from heterocycles $\mathbf{1}$ to the anellated derivatives 2-4 and model peptides 5 and 6, one can see that the formation of [Pharm-Pept 5] complex by the mechanism of the $\pi$, $\pi$-stacking interactions should be more efficient for compounds 1, and [Pharm-Pept 6] is more effective for anellated derivatives $\mathbf{2 - 4}$.

The peptide bond $=\mathrm{C}(\mathrm{O})-\mathrm{NH}-$ can exist in two conformations (cis- and trans-) relative to the polypeptide chain plane [34-35]. Two possible [Pharm-Pept 5] complexes with the oxazole $\mathbf{1 b}$ were calculated. For other molecules (1a and 1c), the complex was calculated with peptide $\mathbf{5}$ in the trans-configuration. The binding energies calculated for different complexes [Pharm-Pept 5] of compounds $\mathbf{1}$ with the model peptide $\mathbf{5}$ are presented in Table 3.

Stabilization energies of [1b-Pept 5 (cis-)] and [1b-Pept $\mathbf{5}$ (trans-)] complexes differ considerably: $\approx 3 \mathrm{kcal} / \mathrm{mol}$; then the complex with the cis-isomer is more stable. Also, our modeling shows that the binding energy of the complex [Pharm-Pept] is sensitive to the nature of heteroatom $\mathrm{X}$; going from the oxazole $\mathbf{1 b}(\mathrm{X}=\mathrm{O})$ to imidazole $\mathbf{1 a}$ and 
thiazole $1 \mathrm{c}$ increases the complex stability to $\approx 2 \mathrm{kcal} / \mathrm{mol}$ and $\approx 10 \mathrm{kcal} / \mathrm{mol}$ respectively. However, there is no direct correlation between stabilization energy and parameter $\varphi_{0}$; it seems to be connected with the different energy gaps $\Delta$.

Table 3. The binding energies of $\pi$-complexes of the compounds 1a-c with model peptide $\mathbf{5}$.

\begin{tabular}{ccccc}
\hline Compd & $\mathrm{E}_{\mathrm{mol}}{ }^{\mathrm{a}}$, a.u. & \multicolumn{3}{c}{ [Compound-Pept 5] } \\
\cline { 3 - 5 } & & $\begin{array}{c}\mathrm{E}_{\mathrm{compl}}{ }^{\mathrm{b}}, \\
\text { a.u. }\end{array}$ & $\begin{array}{l}\mathrm{E}_{\text {compl }}{ }^{\mathrm{c}}, \\
\text { a.u. }\end{array}$ & $\begin{array}{c}\Delta \mathrm{E}^{\mathrm{d}}, \\
\mathrm{kcal} / \mathrm{mol}\end{array}$ \\
\hline $\mathbf{1 b}$ & -245.992 & - & -494.458 & -9.30 \\
$\mathbf{1 b}$ & -245.992 & -494.457 & - & -12.11 \\
$\mathbf{1 a}$ & -226.147 & - & -474.616 & -11.13 \\
$\mathbf{1 c}$ & -568.951 & - & -817.434 & -19.76 \\
$\mathbf{5}^{\text {(trans-) }}$ & -248.451 & & & \\
$\mathbf{5}^{\text {(cis-) }}$ & -248.446 & & & \\
\hline
\end{tabular}

${ }^{\mathrm{a}} \mathrm{E}_{\text {compd }}$ is a total energy of compounds;

${ }^{b} \mathrm{E}_{\text {compl }}$ is a total energy of [Compound-Pept 5] complex, where the peptide bond is in the cis-position;

${ }^{c} \mathrm{E}_{\text {compl }}$ is a total energy of [Compound-Pept 5] complex, where the peptide bond is in the trans-position;

${ }^{\mathrm{d}} \Delta \mathrm{E}$ is a binding energy, calculated by equation (1).

Now, let us estimate the effect of expansion of the conjugated system oxazole and its derivatives during anellation. Firstly, it should be noted that bicyclic molecules 2-4 have a common plane of overlap with both peptide 5 and dipeptide 6. For sake of illustration, Figure 3 shows the optimized geometries of the complexes of the benzoxazole $\mathbf{2 b}$ with the model molecules $\mathbf{5}$ and $\mathbf{6}$ :

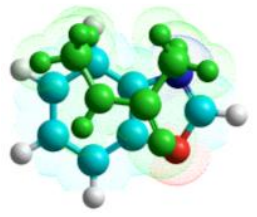

(a)

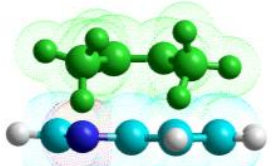

(a)
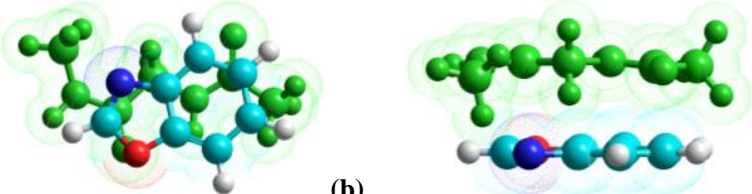

(b)

(b)

Figure 3. Mutual arrangement of both components in $\pi$ - $\pi$-complex [Pharm-Pept]: a) compound $\mathbf{2} \mathbf{b}$ with model peptide $\mathbf{5}$ residue in $\mathrm{X}-\mathrm{Y}$ plane and $\mathrm{X}-\mathrm{Z}$ plane; $\mathrm{b})$ compound $\mathbf{2} \mathbf{b}$ with model dipeptide $\mathbf{6}$ residue in $\mathrm{X}-\mathrm{Y}$ plane and $\mathrm{X}-\mathrm{Z}$ plane.

As indicated in Table 2 and Figure $2 b$, anellation is accompanied by the convergence of the frontier levels. This should increase the energy interaction between the vacant levels of the pharmacophore and occupied levels of the model peptide molecule according to equation (2). The same conclusion concerns the interaction between the occupied levels of the pharmacophore and vacant levels of the model peptide molecule. Hence, the stability of [Pharm-Pept] $\pi$-complex upon anellation should increases. The calculated binding energies in the complexes of the anellated molecules 2-4 with the model peptide 5 and dipeptide $\mathbf{6}$ are collected in Table 4.

Table 4. The binding energies of $\pi$-complexes of the compounds $2 \mathbf{b}, 3$ and $\mathbf{4}$ with model peptides 5 and $\mathbf{6}$.

\begin{tabular}{|c|c|c|c|c|c|c|}
\hline \multirow[t]{2}{*}{ Compd } & \multirow[t]{2}{*}{ anellation } & \multirow[t]{2}{*}{$\mathrm{E}_{\mathrm{mol}}^{\mathrm{a}}$, a.u. } & \multicolumn{2}{|c|}{ [Compound-Pept 5] } & \multicolumn{2}{|c|}{ [Compound-Pept 6] } \\
\hline & & & $\mathrm{E}_{\mathrm{compl}}^{\mathrm{b}}$, a.u. & $\begin{array}{c}\Delta \mathrm{E}^{\mathrm{c}} \\
\mathrm{kcal} / \mathrm{mol}\end{array}$ & $\mathrm{E}_{\text {compl }}$, a.u. & $\begin{array}{c}\Delta \mathrm{E}, \\
\mathrm{kcal} / \mathrm{mol}\end{array}$ \\
\hline $2 b$ & Benzene & -399.586298485 & -648.060865334 & -14.48 & -856.02241454 & -30.60 \\
\hline 3 & Pyridine & -415.62782517 & -664.09305761 & -8.63 & -872.056904788 & -26.19 \\
\hline 4 & Pyrimidine & -431.65161043 & -680.1122263 & -5.73 & -888.07587177 & -23.16 \\
\hline peptide 5 & & -248.451486374 & & & & \\
\hline peptide 6 & & -456.387350963 & & & & \\
\hline
\end{tabular}

${ }^{\mathrm{a}} \mathrm{E}_{\text {compd }}$ is total energy of compounds;

${ }^{\mathrm{b}} \mathrm{E}_{\mathrm{compl}}$ is total energy of [Compound-Pept] complex;

${ }^{\mathrm{c}} \Delta \mathrm{E}$ is a binding energy, calculated by equation (1).

Comparing Tables 3 and 4 shows that anellation of the compounds 1 leads to sensible increasing of the binding energies. Going to the possible complex with the dipeptide 6 (with two parallel peptide conjugated systems) increases twofold the stabilization energy.
At the same time, the data in Table 4 point that replacing of methine groups in benzene ring by the more electronegative nitrogen atoms decreases the highest occupied level of pharmacophore and hence it holds away from the vacant level of the peptide; hence the stabilization energy decreases in the series of the compounds $\mathbf{2} \rightarrow \mathbf{3} \rightarrow \mathbf{4}$. 


\section{Complex stabilized by hydrogen bonds}

Another type of the stable [Pharm-BioM] complexes is formed by generation of the hydrogen bonds between the components (further: [HB]-complex). In this complex the nitrogen atoms with LEP are considered as acceptor centers of such hydrogen bonds. Also, the molecules studied can form hydrogen bonds with some amino acids in proteins containing the functional groups $-\mathrm{NH}_{2},-\mathrm{OH},-\mathrm{SH}$. For sake of comparison, the possible complex with model amino acid residues are $\mathrm{H}_{3} \mathrm{C}-\mathrm{Y}-\mathrm{H}$, were $\mathrm{Y}=\mathrm{NH}, \mathrm{O}, \mathrm{S}$; the nonconjugated fragment in amino acids was modeled by methyl group. Therefore, the various conformation will not taken into consideration: we optimistically suppose that we can neglect different conformations. Besides, we will compare stabilization energies of [HB]-complexes in the series of structurally similar compounds. Before the optimization procedure, complex components were disposed at the distance of $2.1 \AA$; Y-H bond was in the plane, whereas the component planes in the complex were disposed perpendicularly. For molecules 3-4 containing 2 or 3 nitrogen atoms (Figure 4) all possible isomeric complexes were calculated.
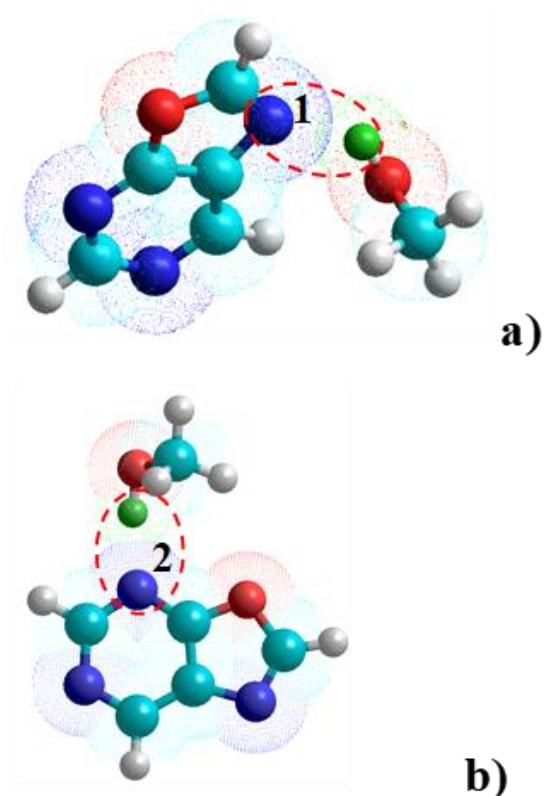

b)

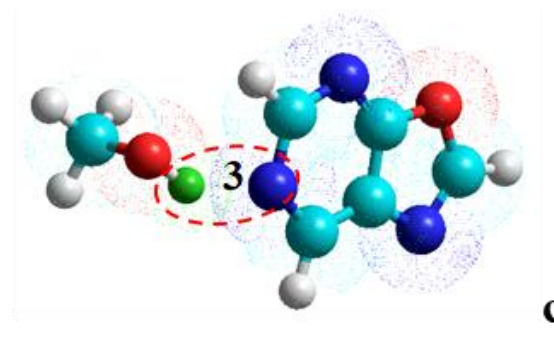

c)

Figure 4. Possible options for creating a $[\mathrm{HB}]$-complex by the mechanism of hydrogen bonding for compound 4 .
It is assumed that the energy and length of the hydrogen bond in the $[\mathrm{HB}]$-complex depend on charge on the nitrogen atom; then the stability of such an isomeric [HB]complex should be different.

First of all, the $[\mathrm{HB}]$-complex of the simplest molecules 1, 2 with model functional amino acid residues will be considered in order to study the dependence of the [HB]complex stability on chemical composition of the model functional molecule $\mathrm{H}_{3} \mathrm{C}-\mathrm{Y}-\mathrm{H}$. The calculated binding energies are presented in Table 5.

Table 5 shows that the nitrogen atom of compounds 1-2 has a relatively large negative charge, its value depends on the nature of the heteroatom $\mathrm{X}$. When compounds $\mathbf{1}$ are annelated, the charge on the nitrogen atom increases, also depending on the nature of the heteroatom $\mathrm{X}$. This charge sensitivity should affect the stability of the [HB]-complex.

Variation of the functional residues in the model molecule $\mathrm{H}_{3} \mathrm{C}-\mathrm{Y}-\mathrm{H}$ shows that the most stable [HB]complex of compounds $\mathbf{1}$ is formed with OH-group; a similar tendency is observed for a number of benzoanalogues $\mathbf{2}$, anellation of the compounds $\mathbf{1}$ increases the binding energy.

Replacing of the heteroatom also is accompanied by the [HB]-complex stability, though anellated benzothiazole 2c $(\mathrm{X}=\mathrm{S})$ is considerably less stable, which seems to be connected with a high energy of the $n$-MO that is the LEP on the sulfur atom. Additionally, the H••S- hydrogen bond is somewhat lengthened.

Going from the simplest oxazole $\mathbf{1}$ to its derivatives $\mathbf{3}$ and $\mathbf{4}$ anellated by the pyridine or pyrimidine, two or even three types of the [HB]-complexes could be formed by the hydrogen bond, as shown in Figure 4. The binding energies calculated for all possible [HB]-complexes with the model molecule $\mathrm{H}_{3} \mathrm{C}-\mathrm{O}-\mathrm{H}$ are presented in Table 6 .

Firstly, negative charge at the nitrogen atom (1) is weakly sensitive on the change of the benzene ring to pyridine and pyrimidine cycles. Going from the molecule 2b to its nitrogen analogue $\mathbf{3}$ decreases slightly the binding energy of the $[\mathrm{HB}]$-complex formed via hydrogen bonding with the nitrogen atom in 5-membered oxazole cycle. In the same time, for derivative $\mathbf{4}$, annelated by the pyrimidine cycle, the stabilization energy $\approx 4 \mathrm{kcal} / \mathrm{mol}$ was predicted by calcularions. The analyses of both possible [HB]complexes with molecule $\mathbf{3}$ shows that the forming of the [HB]-complex with the nitrogen atoms (2) and (3) is less stable $(\approx 1.8 \mathrm{kcal} / \mathrm{mol})$. One can also see that all three isomeric complexes with the molecule $\mathbf{4}$ are appreciably stable. Besides, the Table 5 demonstrates that these isomers differ sizeable between them, the [HB]-complex bonded by the hydrogen bond with the nitrogen atom (1) is most stable.

Finally, let us consider the [HB]-complexes of peptide molecules 5 as hydrogen-bonded complexes with the $\mathrm{N}-\mathrm{H}$ proton donors. The calculated data are collected in Table 7. 
Table 5. Hydrogen bond energy values for the complexes [Compound-H-X] involving compounds $\mathbf{1 - 2}(\mathbf{a}-\mathbf{c})$ with $\mathrm{H}_{3} \mathrm{C}-\mathrm{Y}-\mathrm{H}$.

\begin{tabular}{|c|c|c|c|c|c|c|}
\hline Complex & $\mathrm{H}-\mathrm{X}$ & $z^{\mathrm{a}}$, e.u. & $L^{\mathrm{b}}, \AA$ & $\mathrm{E}_{\text {compd }}{ }^{\mathrm{c}}$, a.u. & $\mathrm{E}_{\mathrm{compl}}^{\mathrm{d}}$, a.u. & $\begin{array}{c}\Delta \mathrm{E}^{\mathrm{e}} \\
\mathrm{kcal} / \mathrm{mol}\end{array}$ \\
\hline [compound 1b-HX] & $\mathrm{H}_{2} \mathrm{~N}-\mathrm{CH}_{3}$ & -0.430 & 2.434 & -245.99202 & -341.83384 & -7.92 \\
\hline [compound 1b-H-X] & $\mathrm{H}-\mathrm{O}-\mathrm{CH}_{3}$ & -0.430 & 1.949 & -245.99202 & -361.69005 & -8.22 \\
\hline [compound 1b-H-X] & $\mathrm{H}-\mathrm{S}-\mathrm{CH}_{3}$ & -0.430 & 2.283 & -245.99202 & -684.670094 & -6.57 \\
\hline [compound 1a-H-X] & $\mathrm{H}-\mathrm{O}-\mathrm{CH}_{3}$ & -0.449 & 1.922 & -226.14680 & -341.84861 & -10.59 \\
\hline [compound 1c-H-X] & $\mathrm{H}-\mathrm{O}-\mathrm{CH}_{3}$ & -0.359 & 1.973 & -568.95108 & -684.67167 & -22.37 \\
\hline [compound $\mathbf{2 b}-\mathrm{H}-\mathrm{X}$ ] & $\mathrm{H}_{2} \mathrm{~N}-\mathrm{CH}_{3}$ & -0.474 & 2.503 & -399.59471 & -495.43508 & -7.02 \\
\hline [compound $\mathbf{2 b}-\mathrm{H}-\mathrm{X}$ ] & $\mathrm{H}-\mathrm{O}-\mathrm{CH}_{3}$ & -0.474 & 1.978 & -399.59471 & -515.295092 & -9.69 \\
\hline [compound $2 \mathbf{b}-\mathrm{H}-\mathrm{X}$ ] & $\mathrm{H}-\mathrm{S}-\mathrm{CH}_{3}$ & -0.474 & 2.454 & -399.59471 & -838.275012 & -7.96 \\
\hline [compound 2a-H-X] & $\mathrm{H}-\mathrm{O}-\mathrm{CH}_{3}$ & -0.500 & 1.943 & -379.74776 & -495.45252 & -12.44 \\
\hline \multirow[t]{4}{*}{ [compound 2c-H-X] } & $\mathrm{H}-\mathrm{O}-\mathrm{CH}_{3}$ & -0.417 & 1.959 & -722.57396 & -838.27227 & -8.40 \\
\hline & \multicolumn{3}{|c|}{$\mathrm{H}-\mathrm{O}-\mathrm{CH}_{3}$} & -115.684935 & - & - \\
\hline & \multicolumn{3}{|c|}{$\mathrm{H}_{2} \mathrm{~N}-\mathrm{CH}_{3}$} & -95.8292016 & - & - \\
\hline & \multicolumn{3}{|c|}{$\mathrm{H}-\mathrm{S}-\mathrm{CH}_{3}$} & -438.667606 & - & - \\
\hline
\end{tabular}

${ }^{\mathrm{a}} \mathrm{z}$, e.u. is the charge on the nitrogen atom, electronic units;

bl is the length of the hydrogen bond;

${ }^{c} \mathrm{E}_{\text {compd }}$ is the energy of the compounds;

${ }^{\mathrm{d}} \mathrm{E}_{\mathrm{compl}}$ is the energy of the [Compound- $\left.H-X\right]$ complex;

${ }^{\mathrm{e}} \Delta \mathrm{E}$ is the stabilization energy complex, calculated by formula (1).

Table 6. Hydrogen bond energy values for the complexes [Compound- $H-X]$ involving compounds $\mathbf{2 b}$, 3-4 with $\mathrm{H}_{3} \mathrm{C}-\mathrm{O}-\mathrm{H}$.

\begin{tabular}{|c|c|c|c|c|c|c|}
\hline Complex & $\mathrm{N}^{\mathrm{a}}$ & $z^{b}$, e.u. & $l^{\mathrm{c}}, \AA$ & $\mathrm{E}_{\text {compd }}{ }^{\mathrm{d}}$, a.u. & $\mathrm{E}_{\text {compl }}{ }^{\mathrm{e}}$, a.u. & $\begin{array}{c}\Delta \mathrm{E}^{\mathrm{f}}, \\
\mathrm{kcal} / \mathrm{mol}\end{array}$ \\
\hline [compound $\mathbf{2 b}-\mathrm{H}-\mathrm{X}$ ] & 1 & -0.474 & 1.978 & -399.59471 & -515.29509 & -9.69 \\
\hline [compound 3-H-X] & 1 & -0.478 & 2.022 & -415.62783 & -531.32932 & -10.39 \\
\hline [compound 3-H-X] & 2 & -0.497 & 1.993 & -415.62783 & -531.32648 & -8.61 \\
\hline [compound 4-H-X] & 1 & -0.441 & 2.055 & -431.65161 & -547.35840 & -13.71 \\
\hline [compound 4-H-X] & 2 & 0.458 & 2.028 & -431.65161 & -547.35444 & -11.23 \\
\hline \multirow[t]{2}{*}{ [compound 4-H-X] } & 3 & 0.431 & 2.000 & -431.65161 & -547.35725 & -12.99 \\
\hline & \multicolumn{3}{|c|}{$\mathrm{H}-\mathrm{O}-\mathrm{CH}_{3}$} & -115.68494 & - & - \\
\hline
\end{tabular}

a $\mathrm{N}$ - position of the nitrogen atom in the anellated cycle of a substance (according to Figure 4);

${ }^{\mathrm{b}} \mathrm{z}$, e.u. is the charge on the nitrogen atom, electronic units;

clis the length of the hydrogen bond;

${ }^{d} E_{\text {compd }}$ is the energy of the compounds;

${ }^{\mathrm{e}} \mathrm{E}_{\mathrm{compl}}$ is the energy of the [Compound-H-X] complex;

${ }^{\mathrm{f}} \Delta \mathrm{E}$ is the stabilization energy complex, calculated by formula (1).

Comparing Tables 6 and 7 shows similar tendencies obtained for the [Compound-Pept 5] with both model peptide 5 and model molecule $\mathrm{H}_{3} \mathrm{C}-\mathrm{OH}$. However, in contrast to $\mathrm{H}_{3} \mathrm{C}-\mathrm{OH}$, the energy of hydrogen bonding with the nitrogen atom (1) for compound $\mathbf{4}$ is lower than that with the nitrogen atoms (2) and (3). It can be conclude that the [Compound 3-Pept 5] and [Compound 4-Pept 5] complexes formed with the peptide moieties of the untwisted part of the protein at the nitrogen atoms of the pyridine type are more stable.

It is to noticed that the some [Compound-Pept 5] could be simultaneously formed for the molecules $\mathbf{3}$ and $\mathbf{4}$ with two or even three hydrogen bonds. This should additionally stabilize the [Pharm-Pept $]$ complex. 
Table 7. Stabilization energies for [Compound-Pept 5] complexes of molecules 1-4 with model peptide 5 .

\begin{tabular}{lcccc}
\hline \multicolumn{1}{c}{ Complex } & $\mathrm{N}^{\mathrm{a}}$ & $\begin{array}{c}\mathrm{E}_{\text {compd }}{ }^{\mathrm{b}}, \\
\text { a.u. }\end{array}$ & $\begin{array}{c}\mathrm{E}_{\mathrm{compl}}{ }^{\mathrm{c}}, \\
\text { a.u. }\end{array}$ & $\begin{array}{c}\Delta \mathrm{E}^{\mathrm{d}}, \\
\mathrm{kcal} / \mathrm{mol}\end{array}$ \\
\hline [compound 1b-Pept 5] & 1 & -245.992 & -494.46044 & -10.63 \\
[compound 2b-Pept 5] & 1 & -399.595 & -648.06555 & -12.14 \\
[compound 3-Pept 5] & 1 & -415.628 & -664.09780 & -11.73 \\
[compound 3-Pept 5] & 2 & -415.628 & -664.09637 & -10.70 \\
[compound 4-Pept 5] & 1 & -431.652 & -680.11718 & -8.84 \\
[compound 4-Pept 5] & 2 & -431.652 & -680.11929 & -10.16 \\
[compound 4-Pept 5] & 3 & -431.652 & -680.11929 & -10.15 \\
Peptide 5 & & -248.451 & & \\
\hline
\end{tabular}

${ }^{a} \mathrm{~N}$ - position of the nitrogen atom in the anellated cycle of a substance (according to Figure 4);

${ }^{\mathrm{b}} \mathrm{E}_{\text {compd }}$ is the energy of the compounds;

${ }^{c} \mathrm{E}_{\mathrm{compl}}$ is the energy of the [Compound-Pept 5] complex;

${ }^{\mathrm{d}} \Delta \mathrm{E}$ is the stabilization energy complex, calculated by formula (1).

\section{Conclusions}

In silico the theoretical analysis of the interaction between pharmacophore molecules based on bicyclic nitrogen heterocycles with model peptides shows that the stabilization of [Pharm-Pept] complexes is ensured by the $\pi$, $\pi$-stacking interactions of the pharmacophore molecule systems with the $\pi$-peptide bond system. The expansion of the conjugate heterocyclic compounds by anellation is accompanied by an increase in the acceptor properties of studied heterocycles, stabilizing the [Pharm-Pept] complexes formed by the $\pi, \pi$-stacking interaction mechanism increases. Elongation of the polypeptide chain increases significantly the stabilization energy of the [Pharm-Pept] complexes.

In the formation of complexes by the mechanism of hydrogen bonds between the LEP of the dicoordinated nitrogen atom and the functional groups of amino acids $\mathrm{OH},-\mathrm{NH}_{2},-\mathrm{SH}$ the most stable [HB]-complexes was found for $\mathrm{OH}$-group, the least stable [HB]-complexes was predicted for SH-group. The expansion of the conjugated anellated system is accompanied by an increase in the acceptor properties of nitrogen containing heterocycle as pharmacophores, especially during anellated with pyridine and pyrimidine, which leads to increased stability of the complexes formed by the hydrogen bonding mechanism. The transition to bicyclic conjugate systems with two or three dicoordinated nitrogen atoms provides additional stabilization of [Pharm-BioM] complexes due to the possible simultaneous formation of several hydrogen bonds. The stabilization energy of [HB]-complexes for compounds $\mathbf{2 b}$ and $\mathbf{3}$ with a "free" peptide bond of the extended part of the protein is slightly lower compared to the functional $\mathrm{OH}$-group of amino acids, and for compound 4, on the contrary, $2 \mathrm{kcal} / \mathrm{mol}$ higher. Compound $\mathbf{4}$ is likely to show more pronounced properties in further in vitro studies.
Notes

\section{The authors declare no conflict of interest.}

Author contributions. Ye.S. V.: provision of study materials, computing resources, or other analysis tools. N. V. O.: formulation or evolution of overarching research goals and aims, application of statistical, mathematical, computational, or other formal techniques to analyze study data. S. G. P.: development and design of methodology; creation of models, provision of study materials, computing resources, or other analysis tools. M. V. K.: preparation, creation and presentation of the published work, specifically visualization. O. D. K.: ideas; formulation or evolution of overarching research goals and aims, development or design of methodology; creation of models. V.S.B. ideas; formulation or development of common goals and objectives of the research, verification of results, responsibility for managing and coordinating the planning and implementation of research activities.

\section{References}

1. Kakkar, S.; Narasimhan, B. A comprehensive review on biological activities of oxazole derivatives. BMC Chem. 2019, 13, 171-195.

2. Zhang, H. Z.; Zhao, Z. L.; Zhou, C. H. Recent advance in oxazolebased medicinal chemistry. Eur. J. Med. Chem. 2018, 144, 444-492.

3. Cameron, D. M.; Thompson, J.; March, P. E.; Dahlberg, A. E. Initiation factor IF2, thiostrepton and micrococci in prevent the binding of elongation factor $\mathrm{G}$ to the Escherichia coli ribosome. $J$. Mol. Biol. 2002, 319, 27-35.

4. Rodnina, M. V.; Savelsbergh, A.; Matassova, N. B.; Katunin, V. I.; Semenkov, Yu. P.; Wintermeyer, W. Thiostrepton inhibits the turnover but not the GTPase of elongation factor $\mathrm{G}$ on the ribosome. Proc. Natl. Acad. Sci. U.S.A. 1999, 96, 9586-9590.

5. Lawrence, D. S.; Copper, J. E.; Smith, C. D. Structure-Activity Studies of Substituted Quinoxalinones as Multiple-Drug-Resistance Antagonists. J. Med. Chem. 2001, 44, 594-601.

6. Borst, P. Multidrug resistance: A solvable problem? Ann. Oncol. 1999, 10, 162-164.

7. Nolt, M. B.; Smiley, M. A.; Varga, S. L.; McClain, R. T.; Wolkenberg, S. E.; Lindsley, C. W. Convenient preparation of substituted 5-aminooxazoles via a microwave-assisted Cornforth rearrangement. Tetrahedron 2006, 62, 4698-4704.

8. Fennell, K. A.; Miller, M. J. Syntheses of Amamistatin Fragments and Determination of Their HDAC and Antitumor Activity. Org. Lett. 2007, 9, 1683-1685.

9. Kachaeva, M. V.; Hodyna, D. M.; Obernikhina, N. V.; Pilyo, S. G.; Kovalenko, Y. S.; Prokopenko, V. M.; Kachkovsky, O. D.; Brovarets, V. S. Design, synthesis and evaluation of novel sulfonamides as potential anticancer agents. J. Heterocycl. Chem. 2019, 56, 3122-3134.

10. Liu, X.; Bai, L.; Pan, C.; Song, B.; Zhu, H. Novel 5-Methyl-2[(un)substituted phenyl]-4-\{4,5-dihydro- 3-[(un)substituted phenyl]5-(1,2,3,4-tetrahydroisoquinoline-2-yl)pyrazol-1-yl \}-oxazole Derivatives: Synthesis and Anticancer Activity. Chin. J. Chem. 2009, 27, 1957-1961.

11. Murphy, G. J.; Holder, J. C. Potential new treatments for type 2 diabetes. Trends. Pharmacol. Sci. 2000, 21, 259-265.

12. Marquez, B. L.; Watts, K. S.; Yokochi, A.; Roberts, M. A.;VerdierPinard, P.; Jimenez, J. I.; Hamel, E.; Scheuer, P. J.; Gerwick, W.H. Structure and Absolute Stereochemistry of Hectochlorin, a Potent Stimulator of Actin Assembly. J. Nat. Prod. 2002, 65, 866-871.

13. Kachaeva, M. V.; Hodyna, D. M.; Semenyuta, I. V.; Pilyo, S. G.; Prokopenko, V. M.; Kovalishyn, V. V.; Metelytsia, L. O.; Brovarets, V. S. Design, synthesis and evaluation of novel sulfonamides as potential anticancer agents. Comput. Biol. Chem. 2018, 74, 294-303.

14. Dahlqvist, A.; Leffler, H.; Nilsson, U. J. C1-Galactopyranosyl Heterocycle Structure Guides Selectivity: Triazoles Prefer Galectin-1 and Oxazoles Prefer Galectin-3. ACS Omega 2019, 4, 7047-7053.

15. Youjun, Xu.; Shiwei, W.; Qiwan, Hu; Shuaishi, G.; Xiaomin, Ma; Weilin, Z.; Yihang, S.; Fangiin, Ch.; Luhua, L.; Jianfeng, P. 
CavityPlus: a web server for protein cavity detection with pharmacophore modelling, allosteric site identification and covalent ligand binding ability prediction. Nucleic Acids Res. 2018, 46, 374379.

16. Nisius, B.; Sha, F.; Gohlke, H. Structure-based computational analysis of protein binding sites for function and druggability prediction. J. Biotechnol. 2012, 159, 123-134.

17. Kasper, J.R.; Park, C. Ligand Binding to a High-Energy Partially Unfolded Protein. Protein Sci. 2015, 24, 129-137.

18. Celej, M.S.; Guillermo, G.; Montich, G.G.; Fidelio, G.D. Protein stability induced by ligand binding correlates with changes in protein flexibility. Protein Sci. 2003, 12, 1496-1506.

19. Mortenson, P. N.; Erlanson, D. A.; Esch, I. J. P.; Jahnke, W.; Johnson, C. N.; Fragment-to-Lead Medicinal Chemistry Publications in 2018. J. Med. Chem. 2018, 62, 3857-3872.

20. Neto, L. R.S.; Moreira-Filho, J. T.; Neves, B. J.; Maidana, R. L. B. R.; Guimarães, A. C. R.; Furnham, N.; Andrade, C. H.; Silva, F. P. In silico Strategies to Support Fragment-to-Lead Optimization in Drug Discovery. Front. Chem. 2020, 8, 93-102.

21. Obernikhina, N.; Zhuravlova, M.; Kachkovsky, O.; Kobzar, O.; Brovarets, V.; Pavlenko, O.; Kulish, M.; Dmytrenko, O. Stability of fullerene complexes with oxazoles as biologically active compounds. Appl. Nanosci. 2020, 10, 1345-1353.

22. Zhuravlova, M.Yu.; Obernikhina, N.V.; Pilyo, S.G.; Kachaeva, M.V.; Kachkovsky, O.D.; Brovarets, V.S. In silico binding affinity studies of phenyl-substituted 1,3-oxazoles with protein molecules. Ukr. Bioorg. Acta 2020, 15, 12-19.

23. Velihina, Ye.S.; Obernikhina, N.V.; Pilyo, S.G.; Kachaeva, M.V.; Kachkovsky, O.D.; Brovarets, V.S. In silico study of biological affinity of nitrogenous bicyclic heterocycles: fragment-to-fragment approach. Ukr. Bioorg. Acta 2020, 15, 48-58.

24. Kachaeva, M. V.; Pilyo, S. G.; Zhirnov, V. V.; Brovarets, V. S. Synthesis, characterization, and in vitro anticancer evaluation of 2 substituted 5-arylsulfonyl-1,3-oxazole-4-carbonitriles. Med. Chem. Res. 2019, 28, 71-80.
25. Kachaeva, M. V.; Obernikhina, N. V.; Veligina, E. S.; Zhuravlova, M. Yu.; Prostota, Ya. O.; Kachkovsky, O. D.; Brovarets, V. S. Estimation of biological affinity of nitrogen-containing conjugated heterocyclic pharmacophores. Chem. Heterocycl. Compd. 2019, 55, 448-454.

26. Kachaeva, M. V.; Hodyna, D. M.; Obernikhina, N. V.; Pilyo, S. G.; Kovalenko, Y. S.; Prokopenko, V. M.; Kachkovsky, O. D.; Brovarets, V. S. Dependence of the anticancer activity of 1,3-oxazole derivatives on the donor/acceptor nature of his substitues, $J$. Heterocyclic Chem. 2019, 56, 3122-3134.

27. Frisch, M.; Trucks, G.; Schlegel, H.; Scuseria, G.; Robb, M.; Cheeseman, J.; Montgomery, Jr. J.; Vreven, T.; Kudin, K.; Burant, J.; Millam, J. Gaussian 03, Revision B. 05. Gaussian Inc.: Pittsburgh, PA, Ringraziamenti, 2003.

28. Jordan, M. The meaning of affinity and the importance of identity in the designed world. Interactions 2010, 17, 6-11.

29. Obernikhina, N.V.; Nikolaev, R.O.; Kachkovsky, O.D.; Tkachuk, Z. $\mathrm{Yu}$. $\Pi$-electron affinity of the nitrogenous bases of nucleic acids. Dopov. Nac. akad. nauk Ukr. 2019, 6, 75-81.

30. Bissantz, C.; Kuhn, B.;Stahl, M. A. Medicinal Chemist's Guide to Molecular Interactions, J. Med. Chem. 2010, 53, 5061-5084.

31. Dewar, M. J. S. The molecular orbital theory of organic chemistry, New York: McGraw Hill, 1969, 484 P.

32. Obernikhina, N.; Kachaeva, M.; Shchodryi, V.; Prostota, Ya.; Kachkovsky, O.; Brovarets, V.; Tkachuk, Z. Topological Index of Conjugated Heterocyclic Compounds as Their Donor/Acceptor Parameter. Polycycl. Aromat. Comp. 2019, 40, 1196-1209.

33. Obernikhina, N.; Pavlenko, O.; Kachkovsky, A.; Brovarets, V. Quantum-Chemical and Experimental Estimation of Non-Bonding Level (Fermi Level) and $\pi$-Electron Affinity of Conjugated Systems. Polycycl. Aromat. Comp. 2020, 2020, 1-10.

34. Palmer, T.; Bonner, P. L. The Biosynthesis and Properties of Proteins. Enzymes 2011, 7, 44-66.

35. Craveur, P.; Joseph, A.P.; Poulain, P. et al. Cis-trans isomerization of omega dihedrals in proteins. Amino Acids 2013, 45, 279-289.

\title{
In silico дослідження взаємодії гетероциклічних основ 3 пептидними групами білків: пофрагментний підхід
}

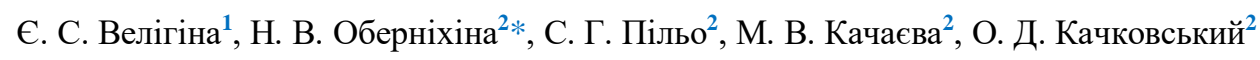 \\ ${ }^{1}$ Інститут біоорганічної хімї̈ та нафтохімї ім. В. П. Кухаря НАН Украӥни, вул. Мурманська, 1, Київ, 02094, Украӥна. \\ ${ }^{2}$ Начіональний медичний університет імені О. О. Богомольия, бульв. Т. Шевченка, 13, Київ, 01601, Украӥна.
}

Резюме: В рамках підходу «фрагмент до фрагменту» представлені in silico результати біологічної спорідненості модельних пептидів (Пепт) та гетероциклічних основ, конденсованих 3 піридином та піримідином, як фармакофорів (Фарм). Аналіз даних показує, що розширення кон'югованих гетероциклічних сполук за допомогою анелювання супроводжується збільшенням акцепторних властивостей досліджуваних гетероциклів, в результаті чого стабільність комплексів [Фарм-Пепт], утворених за механізмом $\pi$, $\pi$-стекінгової взаємодії збільшується. При подовженні поліпептидного ланцюга спостерігається вдвічі збільшення енергії стабілізації комплексів [Фарм-Пепт]. При утворенні комплексів [Фармакофор-Біомолекула] між спряженими гетероциклічними основами з двома-трьома дикоординованими атомами азоту та функціональними групами амінокислот (-OH, - $\mathrm{NH}_{2}$, - $\left.\mathrm{SH}\right)$ за механізмом водневих зв'язків виявились найбільш стабільними комплекси з ОН-групою. Розширення спряженої системи досліджуваних гетероциклів шляхом анелювання 3 піридином та піримідином призводить до підвищеної стабільності комплексів. Енергія комплексоутворення для сполук $\mathbf{2 b}$ та $\mathbf{3}$ із «вільним» пептидним зв'язком розгорнутої частини білка дещо нижча порівняно з енергією комплексів досліджуваних сполук з ОН-групою амінокислот, а для сполуки 4, навпаки, енергія на 2 ккал/моль вище. Сполука 4, ймовірно, проявлятиме більш виражені властивості в подальших дослідженнях in vitro.

Ключові слова: підхід «фрагмент до фрагмента»; пептидні зв’язки; афінність зв’язування; комплекс [Фармакофор-Біомолекула]; л; л-стекінгова взаємодія; водневі зв'язки. 